\title{
1-MCP Releasing Complex for Open-Field Application
}

\author{
Majher I. Sarker ${ }^{1}$, Peggy Tomasula ${ }^{1} \&$ LinShu Liu ${ }^{1}$ \\ ${ }^{1}$ Dairy and Functional Foods Research Unit, Eastern Regional Research Center, Agricultural Research Service, \\ US Department of Agriculture, 600 E. Mermaid Lane, Wyndmoor, PA 19038, USA \\ Correspondence: LinShu Liu, Eastern Regional Research Center, Agricultural Research Service, US Department \\ of Agriculture, 600 E. Mermaid Lane, Wyndmoor, PA 19038, USA. Tel: 1-215-233-6486. E-mail: \\ LinShu.Liu@ARS.USDA.GOV
}

\author{
Received: August 28, 2015 Accepted: October 26, 2015 Online Published: November 23, 2015 \\ doi:10.5539/jps.v5n1p1 \\ URL: http://dx.doi.org/10.5539/jps.v5n1p1
}

\begin{abstract}
1-Methylcyclopropene (1-MCP) is a gas at room temperature which makes it difficult to handle and limits its application to use in closed environments. Open field application of 1-MCP can be a solution to protect crops from environmental stresses like drought or water logging. Our previous studies showed that Boronized-MCP is stable at ambient conditions and can gradually release 1-MCP when in contact with water. In this study the new complexes, suitable for being used directly in open crop fields have been generated and analyzed and also the effectiveness of the previously reported complexes in an open environment has been investigated. This new generation of boron complexes releases 1-MCP in a controlled way upon water contact without emitting any other volatile substances and thus expands their field of application.
\end{abstract}

Keywords: Boron derivatives of methylene cyclopropane, 1-MCP, open field application, plant growth regulator

\section{Introduction}

Ethylene is a plant hormone which plays a role at different stages of plant physiological changes, such as in the opening of flowers, the ripening of fruits or the yellowing of leaves. There are three groups of compounds that bind to the ethylene receptors of plant tissue (Sisler \& Serek, 2003). 1-MCP belongs to one of the three groups in which a single exposure of plant tissue to these compounds is enough to prevent ethylene from binding even at very high levels of ethylene concentration, although this action disappears after a certain time either due to diffusion of the compounds from the binding sites or the development of new receptors (Bayer 1976a, 1976b, 1978; Sisler \& Blankenship, 1993; Sisler et al., 1996a, 1996b, 1999; Sisler \& Serek, 1997, 1999; Veen, 1983). The tight binding characteristic of 1-MCP to the ethylene receptor in plants blocks the activities of ethylene (Serek et al., 1995a, 1995b; Sister \& Serek, 2003; Blankenship \& Dole, 2003). Previous studies showed the affinity of 1-MCP for the receptors is about 10 times greater than that for ethylene (Watkins, 2006). Under environmental stresses like drought or waterlogging the level of endogenous ethylene is further increased in the plant (Kapuya \& Hall, 1984; El-beltagy \& Hall, 1974) due partly to decreased diffusion and partly to increased synthesis, which overall hampers agricultural yields around the world.

1-MCP is a bio-pesticide approved by the EPA for use on fruits and vegetables because of its nontoxic mode of activity (EPA 2002), negligible residues and effectiveness at low concentrations (Serek et al., 1995; Sisler \& Blankenship, 1996; Feng et al., 2004). It is used commercially to keep fruit, flowers or vegetables fresh by preventing or delaying the natural ripening process. It is also used to prevent premature wilting, leaf yellowing, premature opening of flowers as well as premature death (Chow et al., 2006; De Paepe \& Van der Straeten, 2005) and can also reduce the effect of water stress level in plants by inhibiting the ethylene response (Kawakami et al., 2010). However, because 1-MCP is a gas at ambient temperature it is difficult to handle and ship and to control its release. Due to these difficulties, 1-MCP cannot be used in an open crop field which could have a positive impact on increasing overall crop production.

In 2010, about \$161.6 billion worth of food was discarded in the USA alone (Buzby et al., 2014), most of which was rotting fruits and vegetables. So the ability to keep fruits and vegetables fresher for a longer period of time could reduce food waste. Among all other factors, drought is the main environmental constraint to crop productivity worldwide. About $45 \%$ of the total agricultural lands worldwide (Bot et al., 2000) are subjected to continuous or frequent drought conditions which reduce the overall crop yields substantially. It has been reported 
that (Kawakami \& Oosterhuis, 2006; Wang \& Asiimwe, 2010) 1-MCP has good impact on crop yield during the dry seasons. For this purpose, investigations have been conducted for last two decades on 1-MCP particularly to address handling the volatile 1-MCP so that it could be used directly in open crop fields. A number of encapsulation agents have been developed to incorporate 1-MCP like molecular sieves (Daly \& Kourelis, 2001), saw dust (Sisler \& Blankenship, 1996), Cucurbit[6]uril (Zhang et al., 2011), modified starch (Gao, 2005) or $\alpha$-cyclodextrin ( $\alpha$-CD) (Basel \& Kostansek, 2009; Chong et al., 2002; Jacobson \& Wehemyer, 2005). Among them $\alpha-C D$ is the most preferred one as it can easily release 1-MCP as a gas when the 1-MCP capsulated complex $(1-\mathrm{MCP} / \alpha-\mathrm{CD})$ is dissolved in water. The $1-\mathrm{MCP} / \alpha-\mathrm{CD}$ complex powder is commercially available under the trade name SmartFresh. However, $\alpha-C D$ would be expensive for widespread use and encapsulation does not allow for a controlled release of 1-MCP. Therefore, it can only be used in enclosed sites, such as coolers, truck trailers, greenhouses, storage facilities and shipping containers. Another challenge of using uncontrolled $1-\mathrm{MCP}$ is the treatment dose as it relates to the maturity stage of the agricultural product. For example, if immature fruit is treated with 1-MCP it might not mature or ripen. On the other hand 1-MCP may not have any influence on matured fruit and in this case there is no justification for the expense in relation to shelf-life extension. To overcome this limitation, a non-volatile 1-MCP derivative named N,N-dipropyl (1-cycloproperrylmethyl) amine (DPCA) has been developed (Sisler et al., 2009). Less effective results have been reported even after 24 hours treatment and physical contact of the liquid chemical with food is required which is undesirable.

The objective of our research is to develop a complex which can release 1-MCP gradually so that it can be used in an open environment to protect crops from drought conditions or any other environmental stresses. To meet this goal we have realized that encapsulation of 1-MCP is not enough but a chemical reaction should be involved in this phenomenon which will liberate 1-MCP as the reaction moves forward. In this case the releasing rate of 1-MCP will depend on the kinetics of the particular chemical reaction. To design such a complex, a number of characteristic properties should be taken under consideration. (a) Sensitivity: The complex should be sensitive to environmentally friendly elements such as air or water to initiate the reaction. (b) Stability and volatility: The complex should be stable under ambient conditions and have a high boiling point. (c) Reaction properties: The 1-MCP releasing reaction should be carried out at ambient conditions without generating any volatiles or low boiling point products except for 1-MCP itself. (d) Toxicity: All products or byproducts should be non-toxic including the complex itself.

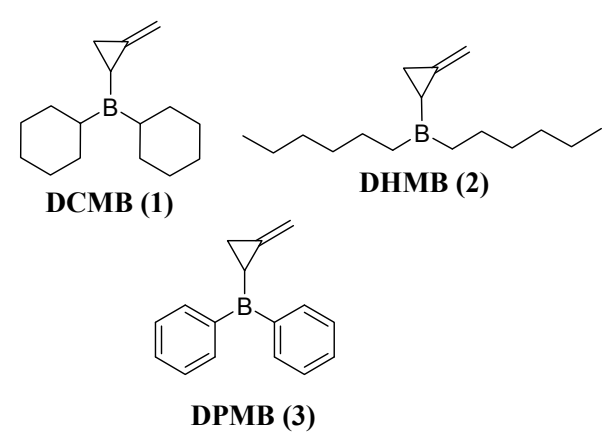

Figure 1. Structure of Boron complexes 1-3

In our previous study (Sarker et al., 2015), the reported synthesized Boron complexes (Figure 1, 1-3) have shown encouraging results toward the gradual release of $1-\mathrm{MCP}$ when reacting with water. The releasing rate of 1-MCP depends on the kinetics of the particular hydrolysis reaction which gives the advantage of selective application. The most encouraging fact about these complexes is that they have the potential of releasing 1-MCP over a long period. The effectiveness of the complexes ( 1 and $\mathbf{3}$ ) has been proved by applying on green tomatoes in a closed environment. However, those compounds also released other compounds such as cyclohexane and cyclohexanol from complex $\mathbf{1}$ or hexane and hexanol from complex $\mathbf{2}$ and benzene from complex $\mathbf{3}$ due to the breakage of other Boron-Carbon bonds. Although these released compounds have much higher boiling points than that of $1-\mathrm{MCP}\left(\sim 12{ }^{\circ} \mathrm{C}\right)$, but they are volatile and some are toxic. Boric acid is also produced as the final product which is practically nontoxic to birds, fish and aquatic invertebrates. Boric acid and its sodium borate salts are active ingredients in pesticide products used as insecticides, acaricides, algaecides, herbicides, fungicides and as wood preservatives (Boric acid, EPA report 2006). In addition to pesticidal uses, boric acid and borate salts may be 
used as soil amendments in boron-deficient soils (OMRI Generic Material List 2013).

As our reported complexes show a strong potential for use in an open environment as a source of 1-MCP in a controlled way, we are encouraged to analyze their effectiveness in an open environment at the first place and secondly, to address the associated limitations of release of volatile chemicals generated by the hydrolysis reactions. This goal is achieved by synthetic structural modification of the complexes. A modification with poly aromatic hydrocarbons (PAH) (Figure 2, 4-10) for the side chains can result in complexes that can be used in dual purposes, gradually releasing 1-MCP and also acting as a pesticide. In this article, we have reported the synthesis and analysis of the complex modified by biphenyl group, BPMB (11) because, biphenyl is solid and prevents the growth of molds and fungus, and is therefore used as a preservative. It can be degraded biologically by conversion into nontoxic compounds (Linden and Sun 2014; Lee et al. 2011; Sakai et al. 2005), some bacteria are able to hydroxylate biphenyl and its polychlorinated biphenyls. Modification with other poly aromatic hydrocarbons will generate the options for particular applications.

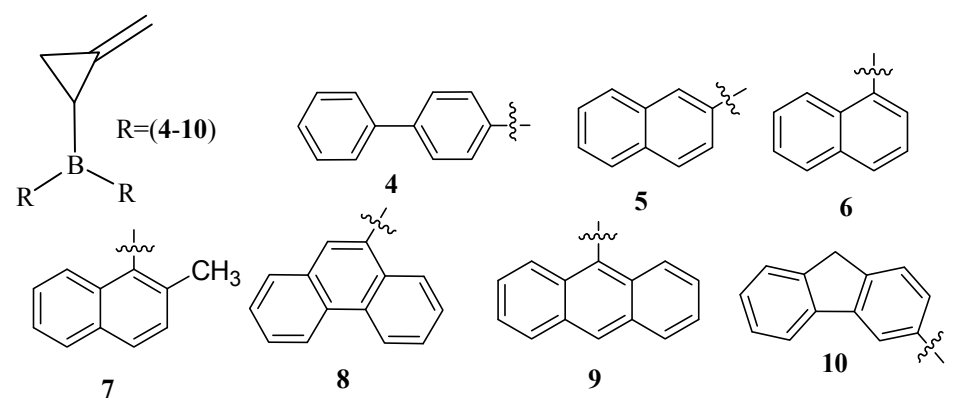

Figure 2. A list of polycyclic aromatic hydrocarbons (PAH)

\section{Materials and Methods}

All the chemicals and solvents used for the synthetic purposes were purchased from Sigma-Aldrich unless otherwise stated. All solvents used were of HPLC grade and moisture dry.

\subsection{Synthesis of Complex BPMB (11) (Figure 3)}

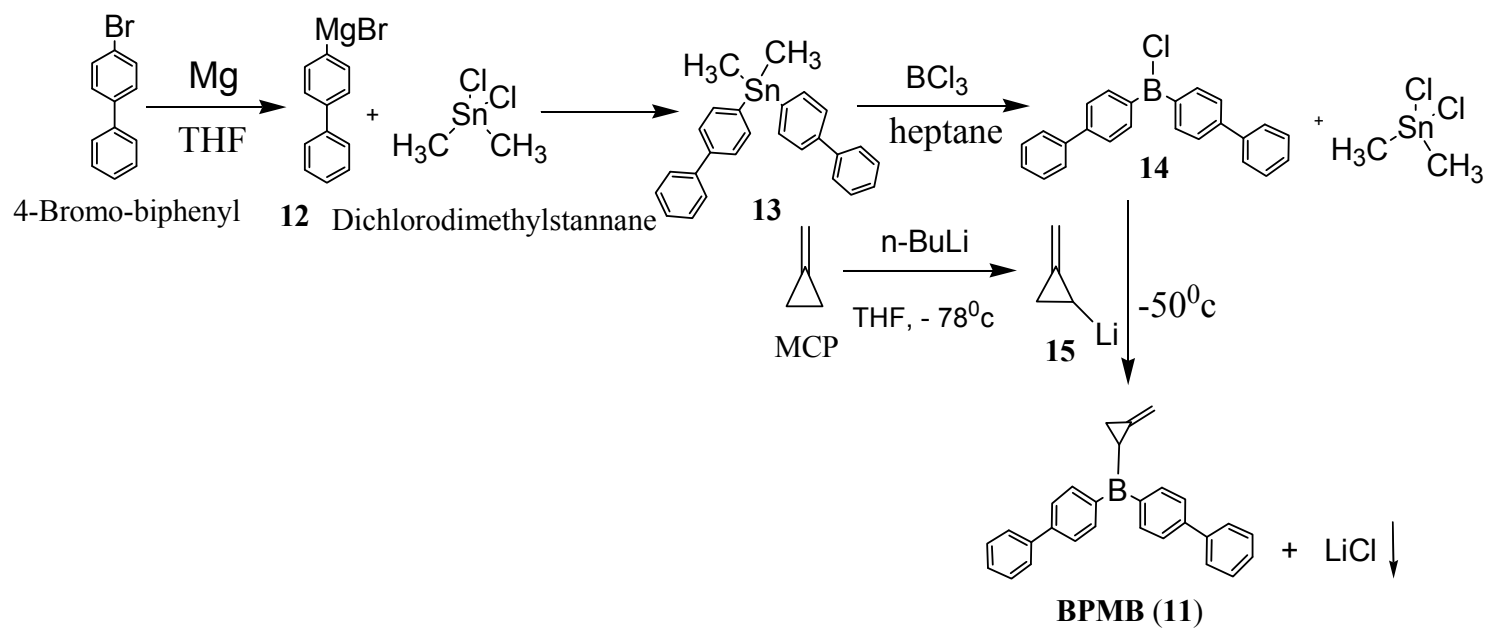

Figure 3. Synthetic scheme of complex BPMB (11)

BPMB (11) has been prepared by the reaction of Bis-biphenyl-4-yl-chloro-borane (14) with lithiated methylenecyclopropane (15), whereas, bis-biphenyl-4-yl-chloro-borane (14) was previously made from the reaction between Bis-biphenyl-4-yl-dimethyl-stannane (13) and boron tricloride in heptane. Bis-biphenyl-4-yl-dimethyl-stannane (13) was synthesized by the reaction of dichlorodimethylstannane with Grignard reagent of 4-bromo-biphenyl (12). Dichlorodimethylstannane and 4-Bromo-biphenyl were purchased from Sigma Aldrich. Methylene cyclopropane (MCP) was prepared from the reaction between 
potassium-[bis(trimethylsilyl)]amide and methallyl chloride (Binger et al., 2002).

\subsubsection{Synthetic Procedure of Bis-biphenyl-4-yl-dimethyl-stannane (13)}

An oven-dried $200 \mathrm{~mL}$ Schlenk flask cooled under argon was charged with $2.4 \mathrm{~g}$ Mg turnings (100 mmol) and $40 \mathrm{~mL}$ of anhydrous THF. To the mixture, $16.6 \mathrm{~g}(71.2 \mathrm{mmol})$ of 4-bromo-biphenyl dissolved in $30 \mathrm{~mL}$ of anhydrous THF was slowly added via a cannula. The reaction mixture was refluxed for $2 \mathrm{~h}$ and cooled at room temperature. The freshly prepared Grignard reagent was transferred via cannula in to a $200 \mathrm{~mL}$ 3-neck flask equipped with a condenser and cooled at $0{ }^{\circ} \mathrm{C}$. A solution of dichlorodimethylstannane $(5 \mathrm{~g}, 22.8 \mathrm{mmol})$ in 10 $\mathrm{mL}$ of dry THF was added in to the 3-neck flask via a cannula. The mixture was stirred for 30 minutes at room temperature before it was refluxed for $3 \mathrm{~h}$. The reaction mixture was stirred at room temperature for $16 \mathrm{~h}$. After the reaction the solution was cooled at $0{ }^{\circ} \mathrm{C}$, treated little by little with total $10 \mathrm{~mL}$ of saturated $\mathrm{NH}_{4} \mathrm{Cl}$ solution and extracted with dichloromethane in a separating funnel. The organic layer was washed three times with total of $150 \mathrm{~mL}$ water, concentrated in vacuo to give crude product mixed with biphenyl. The crude product was mixed with $25 \mathrm{~mL}$ of hexane and filtered under vacuum to obtain $9.6 \mathrm{~g}$ ( $89 \%$ yield) of 13 as white powder. ${ }^{1} \mathrm{H}-\mathrm{NMR}\left(400 \mathrm{MHz}, \mathrm{CDCl}_{3}\right): \delta 0.56(3 \mathrm{H}, \mathrm{s}), 7.33(1 \mathrm{H}, \mathrm{t}, \mathrm{J}=7.5 \mathrm{~Hz}), 7.42(2 \mathrm{H}, \mathrm{t}, \mathrm{J}=7.5 \mathrm{~Hz}), 7.54-7.64(6 \mathrm{H}, \mathrm{m})$; ${ }^{13} \mathrm{C}$ NMR $\left(100 \mathrm{MHz}, \mathrm{CDCl}_{3}\right) \delta-9.98,126.9,127.1,127.3,128.7,136.6,139.3,141.1,141.4$.

\subsubsection{Synthetic Procedure of Bis-biphenyl-4-yl-chloro-borane (14)}

An oven dried $100 \mathrm{~mL}$ thick-walled flask with Teflon screw cap cooled under argon was charged with $5 \mathrm{~g}$ (11 mmol) of bis-biphenyl-4-yl-dimethyl-stannane (13), $11 \mathrm{~mL}$ of $1 \mathrm{M}$ borontrichloride solution (11 mmol) in heptane and $50 \mathrm{~mL}$ of anhydrous heptane in a nitrogen saturated glove box. The mixture was stirred for 30 minutes at room temperature and then heated at $110^{\circ} \mathrm{C}$ for $48 \mathrm{~h}$. After the reaction, the solution was cooled and subjected to vacuum filtration under nitrogen in the glove box. The solid was washed three times with a total 15 $\mathrm{mL}$ of dry dichloromethane to remove dichlorodimethylstannane. The rest of dichlorodimethylstannane was removed by sublimation technique to obtain $1.6 \mathrm{~g}$ of $14(41.3 \%$ yield $)$ as a white powder. ${ }^{11} \mathrm{~B} \mathrm{NMR}\left(\mathrm{CDCl}_{3}\right): \delta$ 63.2; ${ }^{1} \mathrm{H}-\mathrm{NMR}\left(400 \mathrm{MHz}, \mathrm{CDCl}_{3}\right): \delta 7.40(1 \mathrm{H}, \mathrm{t}, \mathrm{J}=7.6 \mathrm{~Hz}), 7.48(1 \mathrm{H}, \mathrm{t}, \mathrm{J}=7.6 \mathrm{~Hz}), 7.68(1 \mathrm{H}, \mathrm{d}, \mathrm{J}=7.6 \mathrm{~Hz})$, $7.74(1 \mathrm{H}, \mathrm{d}, \mathrm{J}=7.6 \mathrm{~Hz}), 8.12(1 \mathrm{H}, \mathrm{d}, \mathrm{J}=8.4 \mathrm{~Hz}) ;{ }^{13} \mathrm{C} \mathrm{NMR}\left(100 \mathrm{MHz}, \mathrm{CDCl}_{3}\right) \delta 126.5,127.3,128.0,128.9$, $136.4,137.6,140.3,145.5$.

\subsubsection{Synthetic Procedure of bis-biphenyl-4-yl-(2-methylene-cyclopropyl)-borane, BPMB (11)}

An oven-dried $100 \mathrm{~mL}$ Schlenk flask cooled at $-78{ }^{\circ} \mathrm{C}$ was charged with MCP $(0.44 \mathrm{~g}, 8.2 \mathrm{mmol})$ in $15 \mathrm{~mL}$ of anhydrous THF. To the solution, $2.5 \mathrm{~mL}$ of $2.5 \mathrm{M} \mathrm{n}$-BuLi in hexane $(6.2 \mathrm{mmol})$ was added slowly and stirred at room temperature for $3 \mathrm{~h}$. The mixture was cooled at $-50{ }^{\circ} \mathrm{C}$ and $2 \mathrm{~g} \quad(5.7 \mathrm{mmol})$ of bis-biphenyl-4-yl-chloro-borane (14) dissolved in $20 \mathrm{~mL}$ of dry THF was added slowly over $15 \mathrm{~min}$ via a cannula. The reaction mixture was stirred at room temperature for $24 \mathrm{~h}$. The solution was filtered to remove salt and concentrated in vacuo. The solid is dissolved in $15 \mathrm{~mL}$ of dichloromethane and filtered with a syringe filter to get a clear solution. The solution was concentrated in vacuo and dried under vacuum to obtain $1.6 \mathrm{~g}$ ( $76 \%$ yield) of BPMB (11) as a solid. ${ }^{11} \mathrm{~B}$ NMR $\left(\mathrm{CDCl}_{3}\right): \delta 33.0$.

\subsection{Sample Preparation of BPMB (11) for the GC Analysis}

GC analysis was conducted to study the controlled release capability of 1-MCP. For BPMB (11), $248 \mathrm{mg}$ of sample was mixed with $0.5 \mathrm{~mL}$ of $\mathrm{H}_{2} \mathrm{O}$ in a $1.5 \mathrm{~mL}$ air tight vial. The vapor collected from the head space of the solution was injected in a GC.

For quantitative GC analysis, a Hewlett-Packard $5890 \mathrm{GC}$ with capillary column $(30 \mathrm{~m} \times 0.25 \mathrm{~mm}$ i.d.) coated with a $0.25 \mu \mathrm{m}$ film of $5 \%$ phenyl methyl silicon and a flame ionization detector was used. The temperature of GC was programmed at $30{ }^{\circ} \mathrm{C}$ isothermal with an injection point temperature of $50{ }^{\circ} \mathrm{C}$. The detector was operated at $230^{\circ} \mathrm{C}$ and sample was injected under split less condition. Helium was used as carrier gas with a 1.5 $\mathrm{mL} / \mathrm{min}$ column flow.

\subsection{Comparative Study of Release of 1-MCP from DCMB (1) and BPMB (11) in Closed Environment at Different Time Segments}

Two air tight 1 liter flasks were separately charged with equivalent amount (1.6 mmol) of DCMB $(378 \mathrm{mg})$ and BPMB $(595 \mathrm{mg}$ ) respectively and $2.5 \mathrm{~mL}$ of water in each flask. The mixtures in both flasks were kept under vigorous stirring. The vapor collected from the head space of the flasks was injected in a GC to quantify the accumulated 1-MCP for three different time segments, 0-24 h, 25-48 h and 49-94 h. After each segment the flasks were kept under vacuum for 20 minutes and flashed with nitrogen. 


\subsection{Treatment of Tomatoes for Quality Analysis in an Open Environment.}

Mature green tomatoes were purchased through a major fruit company (Gargiulo, Inc., Naples, FL.) and stored at $10{ }^{\circ} \mathrm{C}$ before analysis. For the experiment three 1-gal glass jars without lids were used to treat six green tomatoes each. The tomatoes in two jars were treated with 1-MCP released from $1.14 \mathrm{~g}(4.9 \mathrm{mmol})$ of DCMB (1) and 1.13 $\mathrm{g}(3.0 \mathrm{mmol})$ of BPMB (11) respectively. The hydrolysis reaction was initiated with $4.0 \mathrm{~mL}$ of water and carried out in a $14 \mathrm{~mL}$ vial with continuous stirring for both cases. The vial was placed at the bottom of the jars. The third jar was kept in an identical condition without placing any boron complex inside. The treatment was carried out for 7 days at $22{ }^{\circ} \mathrm{C}$. Theoretically, the total of $4.9 \mathrm{mmol}$ and $3.0 \mathrm{mmol}$ of 1-MCP gas are released in DCMB (1) and BPMB (11) jars respectively as one mole 1-MCP is liberated from every equivalent mole of these boron derivatives during hydrolysis reaction. Quality analysis (color and firmness) was performed at $22 \pm 2{ }^{\circ} \mathrm{C}$. Color was measured with a Hunter UltraScan ${ }^{\circledR}$ VIS colorimeter (Hunter Associates Lab, Reston, VA) and firmness was evaluated with a TA-XT2i Texture Analyzer (Texture Technologies Corp., Scarsdale, NY). Four measurements were taken for each tomato for color and firmness. The color of the tomatoes was measured six times during the monitoring period and the firmness was determined in the beginning and at the end of investigation.

\section{Results and Discussion}

The capability of gradual release of 1-MCP from boron complexes encouraged us to perform further research on these compounds. The major limitation associated with the reported complexes (1-3) of our previous study (Sarker et al., 2015) was the generation of volatile solvents as byproducts due to the breakage of additional two $\mathrm{B}-\mathrm{C}$ bonds other than the desired $\mathrm{B}-\mathrm{MCP}$ bond in hydrolysis reaction. This problem mainly generates cyclohexane, hexane and benzene as by products from 1,2 and 3 complexes respectively after reacting with water along with boric acid in common. Although the boiling point of these compounds are much higher $\left(68-81{ }^{\circ} \mathrm{C}\right)$ than that of released 1-MCP $\left(12{ }^{\circ} \mathrm{C}\right)$ making these complexes useful in practical application but the volatility of the released compounds from these complexes limits the extension of their application especially in hot environment. To deal with this challenge we have modified the structure of the complex. Our first effort was to introduce biphenyl, a polycyclic aromatic hydrocarbon $(\mathrm{PAH})$ as it is a solid with pesticidal properties and is also bio-degradable. We have also suggested a series (Figure 2, 4-10) of PAH which have potential to be used as a replacement to generate more complexes suitable for open field application. In synthetic aspect, BPMB (11) includes a four steps synthetic scheme (Figure 3) with a good yield at every step. An important part of this synthetic route is the recovery of dichlorodimethylstannane in the following step that can be reused reducing the synthetic cost of BPMB (11).

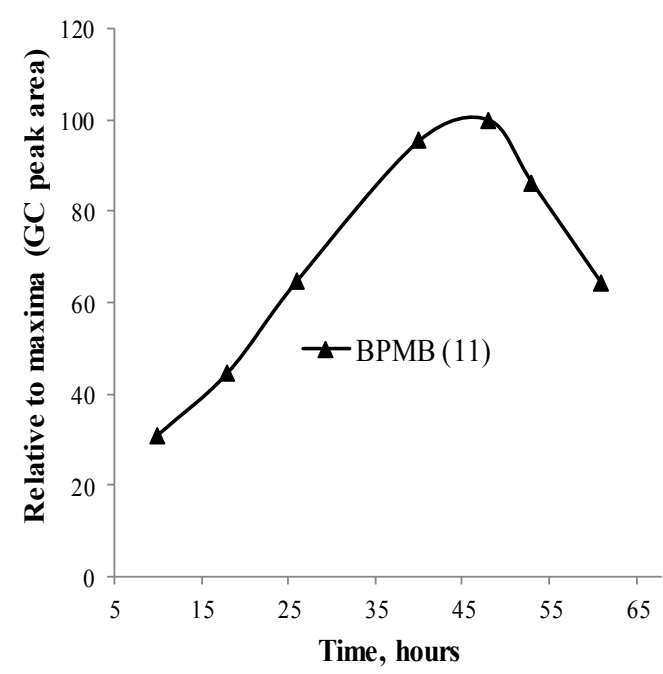

Figure 4. Controlled release of 1-MCP from BPMB (11)

\subsection{Control Release of 1-MCP from BPMB (11)}

From Figures 4 it is clear that BPMB (11) is capable of gradual release of 1-MCP when in contact with water. BPMB (11) requires $48 \mathrm{~h}$ to reach its highest point of release which is long enough to treat the agricultural products either in closed or open environments. After 48 hours, the descending curve indicates the finish line of releasing 1-MCP from the complex. But as we took more 1-MCP out for continued analysis the concentration of 
accumulated 1-MCP was reduced. It shows better resistance in releasing 1-MCP than DCMB, where 21 hours were needed (Sarker et al., 2015) to reach the highest point. Capability of sustained release of 1-MCP makes BPMB (11) a better choice for the application where longer treatment is necessary.

\subsection{Comparative Study of Releasing 1-MCP from DCMB (1) and BPMB (11)}

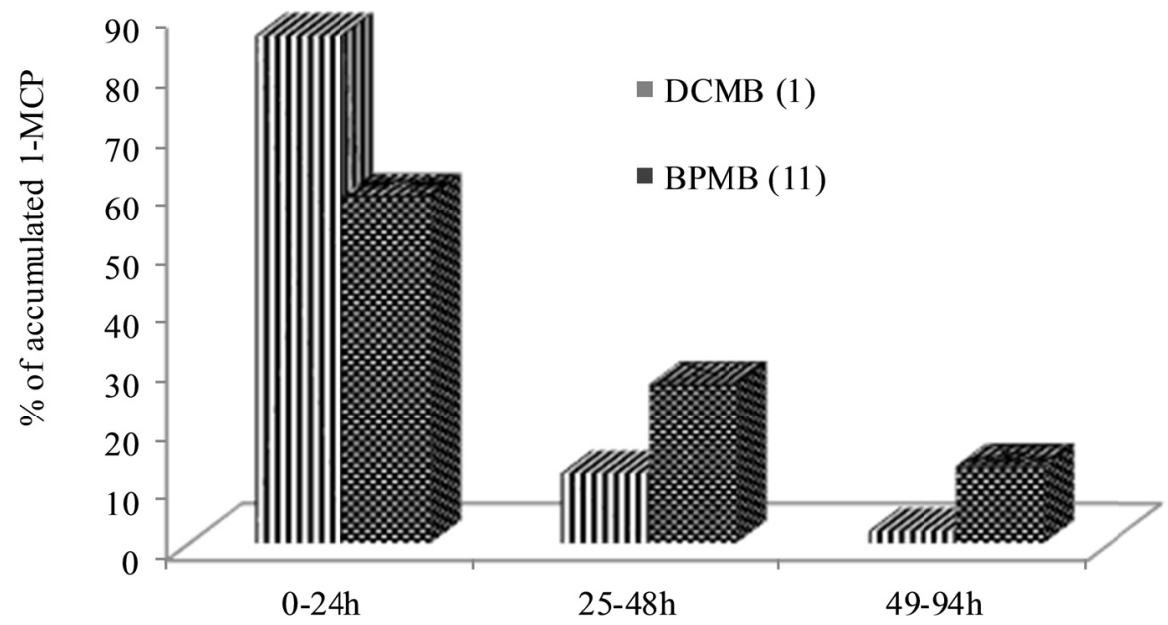

Figure 5. Accumulation of 1-MCP from DCMB (1) and BPMB (11) at different time segments at $22 \pm 2{ }^{\circ} \mathrm{C}$

Comparative study at individual time segment shows that (Figure 5) the releasing pattern of 1-MCP from both complexes is same as they released the major portion in first 24 hours. However, there is a significant difference in releasing rate because DCMB (1) accumulated $86 \%$ of released 1-MCP in $0-24$ hours whereas, BPMB (11) accumulated only 59\%. In between 25-48 hours, DCMB (1) and BPMB (11) accumulated 12\% and 27\% of released 1-MCP respectively, whereas, the rest of $2 \%$ and $13 \%$ of released $1-\mathrm{MCP}$ were accumulated by DCMB (1) and BPMB (11) respectively in next $49-94 \mathrm{~h}$. This unique characteristic of releasing 1-MCP over a long period from these complexes would be useful for selective application and also for multi batch treatment in a closed environment, which will substantially reduce the cost of treatment.

\subsection{Quality Analysis of Tomatoes Treated with DCMB (1) and BPMB (11) in an Open Environment}

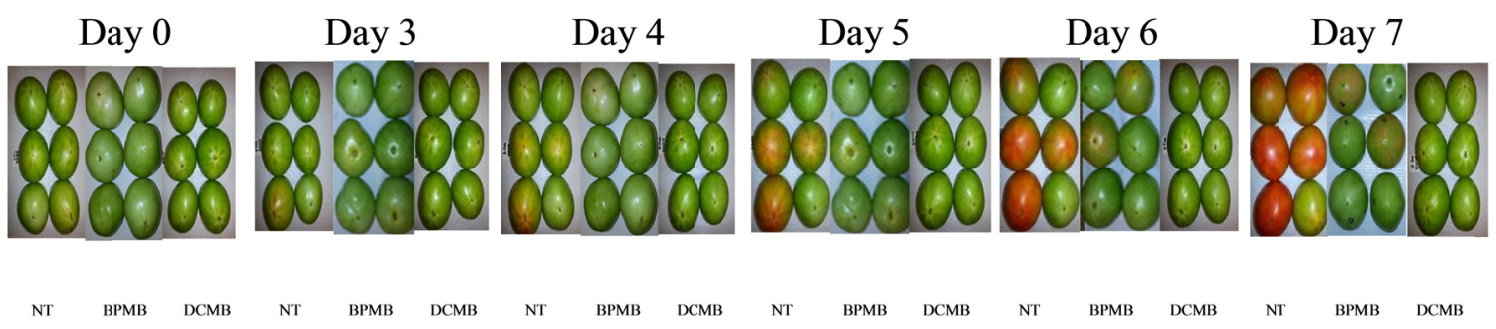

Figure 6. Comparative color changes of treated (DCMB \& BPMB) and non-treated (NT) tomatoes in an open environment

Before claiming efficacy of any of the complexes for use in an open field, it is essential to demonstrate the idea in a practical setting. The result shows that both DCMB (1) and BPMB (11) have the capability to retard the ethylene response on tomatoes even in an open environment. Distinctive color differences were observed after 4 days; where 1-MCP (released from BPMB and DCMB) treated tomatoes remained green but some of the untreated tomatoes (NT) turned yellow or red (Figure 6). At the end of $7^{\text {th }}$ day of investigation, all of the non-treated tomatoes (NT) became red or yellow whereas, 66\% of the BPMB treated tomatoes and all of the DCMB treated tomatoes were still green. No injuries were observed on the surfaces of the treated tomatoes. 

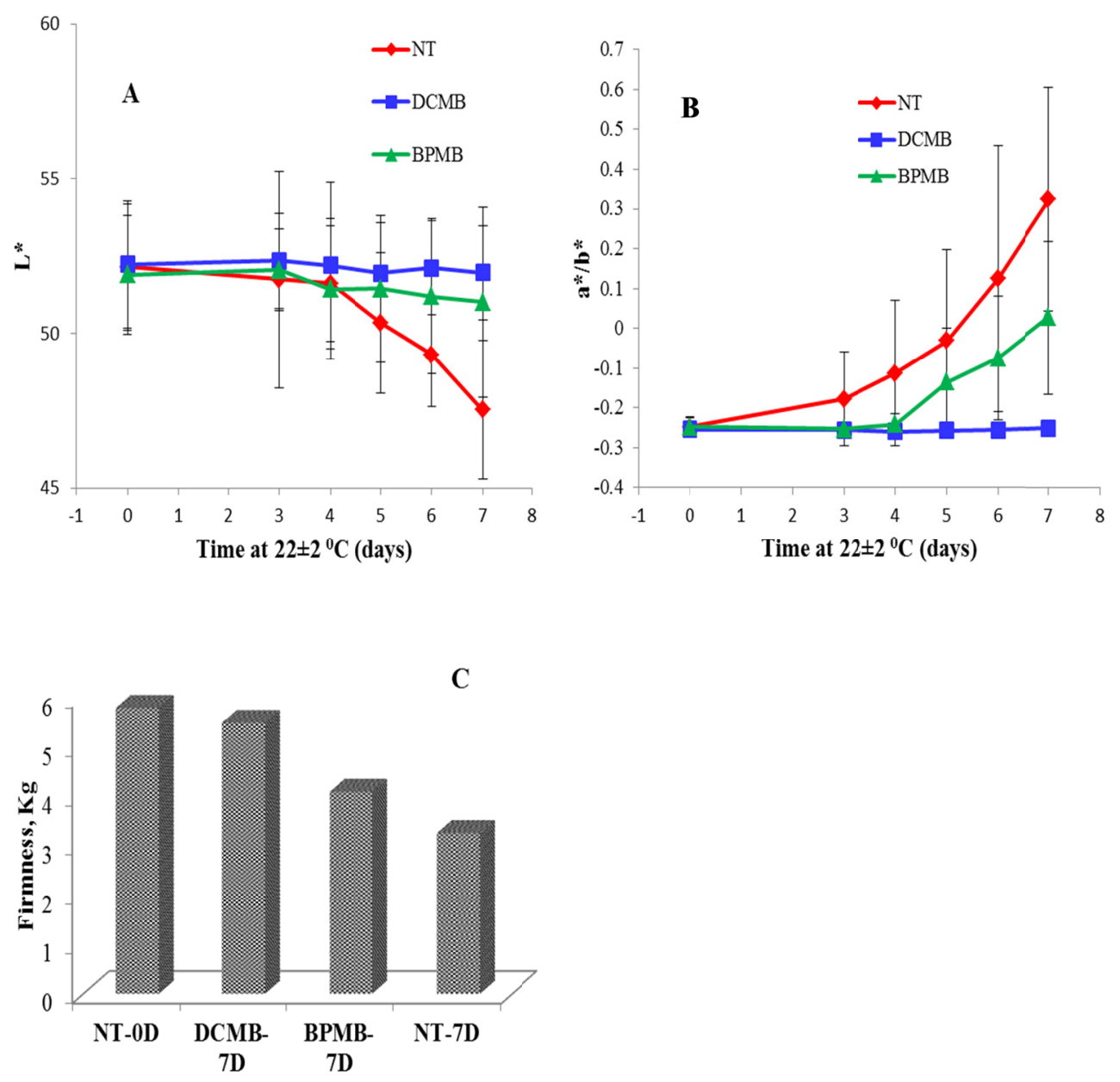

Figure 7. Comparative changes in $\mathrm{L}^{*}(\mathrm{~A}), \mathrm{a}^{*} / \mathrm{b}^{*}(\mathrm{~B})$ and firmness $(\mathrm{C})$ of treated (DCMB and BPMB) and non-treated (NT) tomatoes during storage time in an open environment

For quality analysis, $\mathrm{L}^{*}$ values indicate the darkness of the tomato surface color (Figure $7 \mathrm{~A}$ ). $\mathrm{L}^{*}$ values of the tomatoes which were treated with Boron complex, DCMB (1) and BPMB (11) in open jars were not significantly changed at the end of the $5^{\text {th }}$ day, but the $\mathrm{L}^{*}$ value of the non-treated tomatoes (NT) began decrease significantly from day 5 as some of them became dark red in color. At the end of the $7^{\text {th }}$ day the differences in $\mathrm{L}^{*}$ values were observed by 4 and 5 points between NT-BPMB and NT-DCMB treated tomatoes respectively.

On the other hand, the $\mathrm{a}^{*}$ and $\mathrm{b}^{*}$ values represent the redness and yellowness of tomatoes respectively. The higher the $a^{*}$ values, the redder the tomatoes were. Over 7 days of the experiment, the $a^{*} / b^{*}$ value of the treated tomatoes (BPMB and DCMB) increased slowly or remained constant, where, the $\mathrm{a}^{*} / \mathrm{b}^{*}$ value for the non-treated (NT) tomatoes increased rapidly (Figure 7B). These results suggested that the treated tomatoes were less red in comparison to the non-treated tomatoes (NT) even after 7 days of investigation which is apparent as shown in Figure 6.

The tomatoes which were treated with boron complexes BPMB (11) and DCMB (1) were firmer than the non-treated tomatoes (NT) (Figure 7C) at the end of 7 days. The values of firmness were 5.5, 4.1 and $3.2 \mathrm{~kg}$ for the DCMB (DCMB-7D), BPMB (BPMB-7D) and non-treated (NT-7D) tomatoes respectively, which is a decrease of $5 \%, 29 \%$ and $45 \%$ respectively from the initial value of $5.8 \mathrm{Kg}$ (NT-0D) at day 0 . From overall quality analysis it is evident that both complexes are able to retard the ripening process of tomatoes in an open environment. However, DCMB (1) shows better protection over BPMB (11) which is simply because more equivalent amount of DCMB (4.9 mmol) was used than the equivalent amount of BPMB $(3.0 \mathrm{mmol})$ in this experiment. The different equivalent amounts were taken intentionally to have an idea which level of concentration of released 1-MCP is required to block the ethylene receptor successfully. 


\section{Conclusion}

In this study we have shown that previously reported boron complex DCMB (1) and newly synthesized BPMB (11) can work on tomato fruits even in open environment to retard their ripening process, although a certain concentration level of released 1-MCP is required for better performance. BPMB (11) has the potential to be used directly in open crop field as it gradually releases 1-MCP over a long period so the vicinity of the crop field will have 1-MCP continuously released by boron derivative. It is also important not to produce volatile byproducts due to hydrolysis reaction of the complex like BPMB (11), which generates solid biphenyl as byproduct. These complexes can also be used in close environment for multi batch operation or selective application. Replacement with other Poly Aromatic Hydrocarbons (PAH) can results better complex to be used in open crop field.

\section{Acknowledgment}

We thank Ran Li for her help with acquiring and processing the data for quality analysis of tomatoes.

\section{References}

Bayer, E. M. (1976a). Silver ion: a potent anti-ethylene agent in cucumber and tomato. HortScience, 11, 195-196.

Bayer, E. M. (1976b). A potent inhibitor of ethylene action in plants. Plant Physiology, 58, 268-271. http://dx.doi. org/10.1104/pp.58.3.268

Bayer, E. M. (1978). Method for overcoming the anti-ethylene effects of $\mathrm{Ag}^{+1}$. Plant Physiology, 62, 616-617. http://dx.doi.org/10.1104/pp.62.4.616

Basel, R. M., \& Kostansek, E. C. (2009). Compositions with cyclopropenes and adjuvants. U.S. Patent: $20090088323 A 1$.

Binger, P., Brinkmann, A., \& Wedemann, P. (2002). Highly Efficient Synthesis of Methylene cyclopropane. Synthesis, 10, 1344-1346. http://dx.doi.org/10.1055/s-2002-33122

Blankenship, S. M., \& Dole, J. M. (2003). 1-Methylcyclopropene: a review. Postharvest Biol Technol, 28, 1-25. http://dx.doi.org/10.1016/S0925-5214(02)00246-6

Boric Acid/Sodium Borate Salts. (2006). HED Chapter of the Tolerance Reassessment. Eligibility Decision Document (TRED); U.S. Environmental Protection Agency, Office of Prevention, Pesticides, and Toxic Substances, Health Effects Division, U.S Government Printing Offices: Washington, DC.

Bot, A. J., Nachtergaele, F. O., \& Young. (2000). A Land resource potential and constraints at regional and country levels. World Soil Resources Reports 90. Land and Water Development Division, FAO, Rome.

Buzby, J., Wells, H., \& Hyman, J. (2014). The Estimated Amount, Value and Calories of Postharvest Food Losses at the Retail and Consumer Levels in the United States. Economic Information Bulletin Number, 121, USDA, February 2014.

Chong, J. A., Farozic, V. J., Jacobson, R. M., Synder, B. A., Steephens, R. W., \& Mosley, D. W. (2002). Continuous process for the preparation of encapsulated cyclopropenes. U.S. Patent: 20020043730A1.

Chow, B., \& McCourt, P. (2006). Plant hormone receptors; perception is everything. Genes Dev, 20(15), 1998-2008.

Daly, J., \& Kourelis, B. (2001). Synthesis methods, complexes and delivery methods for the safe and convenient storage, transport and application of compounds for inhibiting the ethylene response in plants. U.S. Patent: 6017849 .

De Paepe, A., \& Van der Straeten, D. (2005). Ethylene biosynthesis and signaling; an overview. Vitam Horm, 72, 399-430. http://dx.doi.org/10.1016/S0083-6729(05)72011-2

El-beltagy, A. S., \& Hall, M. A. (1974). Effect of water stress upon endogenous ethylene levels in Vicia Faba. New Phytol, 73, 47-60. http://dx.doi.org/10.1111/j.1469-8137.1974.tb04605.x

EPA (Environmental Protection Agency). (2002). Fed Regist, 67, 796-800.

Feng, X. Q., Apelbaum, A., Sisler, E. C., \& Goren, R. (2004). Control of ethylene activity in various plant systems by structural analogues of 1-methylcyclopropene. Plant Growth Regul, 42, 29-38. http://dx.doi.org/10.1023/B:GROW.0000014900.12351.4e

Gao, R. T. (2005). Microcapsuled fruit, vegetable and flower antistaling agent and preparation thereof. Chin. 


\section{Patent: 10089065.}

Jacobson, R. M., \& Wehemyer, F. L. (2005). Humidity activated delicery systems for cyclopropenes. Eur. Patent: $1593306 A 2$.

Kapuya, J. A., \& Hall, M. A. (1984). Plant Sensitivity to Endogenous Ethylene in Relation to Species $\begin{array}{lllll}\text { Characteristics. } & \text { Zeitchrift } & \text { fur }\end{array}$ http://dx.doi.org/10.1016/S0044-328X(84)80102-6

Kawakami, E. M., Oosterhuis, D. M., \& Snider, J. L. (2010). Physiological effects of 1-Methylcyclopropene on well-watered and water-stressed cotton plants. J. Plant Growth Regul, 29, 280-288. http://dx.doi.org/10.1007/s00344-009-9134-3

Kawakami, E. M., \& Oosterhuis, D. M. (2006). Effect of 1-MCP on the Physiology and Growth of Drought-Stressed Cotton Plants. Summaries of Arkansas Cotton Research, 62-66.

Lee, T. K., Lee, J., Sui, W. J., Iwai, S., Chai, B., Tiedje, J. M., \& Park, J. (2011). Novel Biphenyl-Oxidizing Bacteria and Dioxygenase Genes from a Korean Tidal Mudflat. Appl Environ Microbiol, 77, 3888-3891. http://dx.doi.org/10.1128/AEM.00023-11

Linden, D., \& Sun, Z. (2014). Biphenyl Pathway Map. Retrieved June 30, 2014, from http://eawag-bd.ethz.ch/bph/bph_map.html

OMRI Generic Materials List. (2013). Organic Materials Review Institute. Retrieved from http://www.omri.org/sites/default/files/app_materials/OMRI-GML-Stan-2013small_0.pdf

Sakai, M., Ezaki, S., Suzuki, N., \& Kurane, R. (2005). Isolation and characterization of a novel polychlorinated biphenyl-degrading bacterium, Paenibacillus sp. KBC101. Appl. Microbiol Biotechnol, 68, 111-116.

Sarker, M., Xuetong, F., \& Liu, L. (2015). Boron derivatives: As a source of 1-MCP with gradual release. Scientia Horticulturae, 188, 36-43.

Serek, M., Sisler, E. C., \& Reid, M. S. (1995a). Effects of 1-MCP on the vase life and ethylene response of cut flowers. Plant Growth Reg, 16, 93-97. http://dx.doi.org/10.1007/BF00040512

Serek, M., Tamari, G., Sister, E. C., \& Boro, A. (1995b). Inhibition of ethylene-induced cellular senescence symptoms by 1-methylcyclopropene, a new inhibitor of ethylene action. Physiol Plant, 94(2), 229-232.

Sisler, E. C., \& Blankenship, S. M. (1993). Diazocyclopentadiene (DACP) a light sensitive reagent for the ethylene receptor in plants. Plant Growth Reg, 12, 125-132. http://dx.doi.org/10.1007/BF00144593

Sisler, E. C., \& Blankenship, S. M. (1996). Method on counteracting an ethylene response in plants. U.S. Patent: 5518988 .

Sisler, E. C., Dupille, E., \& Serek, M. (1996a). Effect of 1-methylcyclopropene and methylenecyclopropane on ethylene binding and ethylene action on cut carnations. Plant Growth Reg, 18, 79-86. http://dx.doi.org/10.1007/BF00028491

Sisler, E. C., Serek, M., \& Dupille, E. (1996b). Comparison of cyclopropene, 1-methylcyclopropene and 3,3-dimethylcyclopropene as ethylene antagonists in plants. Plant Growth Reg, 18, 169-174. http://dx.doi.org/10.1007/BF00024378

Sisler, E. C., Goren, R., Apelbaum, A., Serek, M. (2009). The effect of dialkylamine compounds and related derivatives of 1-methylcyclopropene in counteracting ethylene responses in banana fruit. Postharvest Biology and Technology, 51, 43-48. http://dx.doi.org/10.1016/j.postharvbio.2008.06.009

Sisler, E. C., \& Serek, M. (1997). Inhibition of ethylene responses in plants at the receptor level: Recent developments. Physiol Plant, 100, 577-582. http://dx.doi.org/10.1034/j.1399-3054.1997.1000320.x

Sisler, E. C., Serek, M., Dupille, E., \& Goren, R. (1999). Inhibition of ethylene responses by 1-methylcyclopropene and 3-methylcyclopropene. Plant Growth Reg, 27, 105-111. http://dx.doi.org/10.1023/A:1006153016409

Sisler, E. C., \& Serek, M. (1999). Compounds controlling the ethylene receptor. Bot. Bull. Acad. Sin, 40, 1-7.

Sister, E. C., \& Serek, M. (2003). Compounds interacting with the ethylene receptor in plants. Plant Biol., 5(5), 473-480. http://dx.doi.org/10.1055/s-2003-44782

Veen, H. (1983). Silver thiosulphate: an experimental tool in plant science. Scientia Horticulturae, 20, 211-224. http://dx.doi.org/10.1016/0304-4238(83)90001-8 
Wang, G., \& Asiimwe, R. K. (2010). Effects of 1-MCP and Quadris on cotton growth and yield. Arizona Cotton Report (P-159), 28-33.

Watkins, C. B. (2006). The use of 1-methylcyclopropene (1-MCP) on fruits and vegetables. Biotechnology Advances, 24, 389-409. http://dx.doi.org/10.1016/j.biotechadv.2006.01.005

Zhang, Q., Zhen, Z., Jiang, H., Li, X. G., \& Liu, J. (2011). Encaplulation of the Ethylene Inhibitor 1-Methylcyclopropene by Cucurbit[6]uril. J. Agric Food Chem, 59, 10539-10545. http://dx.doi.org/10.1021/jf2019566

\section{Copyrights}

Copyright for this article is retained by the author(s), with first publication rights granted to the journal.

This is an open-access article distributed under the terms and conditions of the Creative Commons Attribution license (http://creativecommons.org/licenses/by/3.0/). 